\title{
TERAMPIL
}

Jurnal Pendidikan dan Pembelajaran Dasar

\section{ANALISIS PERKEMBANGAN NILAI AGAMA-MORAL SISWA USIA \\ DASAR}

IFAT NABILAH

Email : nabilahifat95@gmail.com

Universitas Islam Negeri Sunan Kalijaga Yogyakarta

ISWATUN KHOIRIAH

Email : iswatunkhoiriah@gmail.com

Universitas Islam Negeri Sunan Kalijaga Yogyakarta

SUYADI

Email : yadi.uinjogja@gmail.com

Universitas Islam Negeri Sunan Kalijaga Yogyakarta

Volume 6 Nomor 2, Desember 2019

\section{Abstract}

The development of religious and moral values of elementary age students is very appropriate and interesting to be studied. This research is intended to analyze the development of the religious and moral values of elementary age children achieved. This research is a descriptive qualitative research with data collection methods using interview techniques. The research subject was a Class VI student. The results showed that there were four factors supporting the achievement of children's religious-moral values on the subject, namely, the child's internal self, family, school and environment. These factors must support each other, supervise, remind, guide, set an example in order to create a generation of people who are religiously religious and moral. This research can be used as a reference in educating the religious-moral behavior of elementary school age students.

Keywords: Child development, Elementary School Students, Religious-Moral Values.

\section{Abstrak}

Perkembangan nilai agama dan moral siswa usia dasar sangat patut dan menarik untuk diteliti. Penelitian ini dimaksudkan untuk menganalisis perkembangan nilai agama dan moral anak usia dasar yang tercapai. Penelitian ini merupakan penelitian kualitatif deskriptif dengan metode pengumpulan data menggunakan teknik wawancara. Subjek penelitiannya seorang peserta didik Kelas VI. Hasil penelitian menunjukkan bahwa faktor pendukung tercapainya nilai agama-moral anak pada subjek ada 4, yakni, internal diri anak, keluarga, sekolah dan lingkungan. Faktor tersebut harus saling mendukung, mengawasi, mengingatkan, membimbing, memberi contoh agar tercipta generasi bangsa yang taat beragama 
IFAT NABILAH,

ISWATUN KHOIRIAH \&

SUYADI

dan bermoral tinggi. Penelitian ini dapat dijadikan referensi dalam mendidik perilaku agama-moral anak didik usia sekolah dasar.

Kata Kunci: Perkembangan anak, Siswa Usia Dasar, Nilai Agama-Moral.

\section{A. PENDAHULUAN}

Nilai agama dan moral pada anak usia sekolah dasar dapat diartikan sebagai perubahan psikis yang dialami anak didik terkait kemampuan memahami dan menerapkan perilaku yang sesuai ajaran agama yang dianutnya. Tingkah laku, tutur kata, pola pikir sering dikaitkan dengan moral seseorang, sedangkan moral agama berkaitan dengan hal-hal yang dianut dan bersumber dari Al-Qur'an dan Hadits. Nilai agama dan moral adalah pondasi awal bagi anak dalam menjalani kehidupan dari berbagai hal yang mungkin terjadi baik dan buruk dalam kehidupan sehari-hari.

Berbagai fenomena perilaku menyimpang sering terlihat dalam kehidupan sehari-hari anak saat ini. Contoh kasus dugaan pengeroyokan siswa SD di Kediri oleh temannya saat bermain sepak bola ditengarai hanya karena melakukan gol bunuh diri terjadi pada Januari 2018 (Damanik, 2018). Masalah terkait nilai agama dan moral anak bermacam-macam seperti bullying, mencuri, merokok, tawuran, melawan orang-tua, seks bebas, narkoba dan sebagainya semakin meresahkan masyarakat khususnya guru dan orang tua. Dapat dikatakan bahwasanya masalah yang juga penting selain meningkatkan kualitas kognitif anak adalah masalah akhlak dan karakter anak. Nilai agama dan moral seorang anak dapat kita ketahui dengan hanya melihat dan memperhatikan sikap ataupun tingkah laku anak sehari-hari yang mencerminkan kepribadiannya.

Pada masa sekolah dasar, anak masih suka mengamati dan meniru apa yang menjadi kebiasaan di lingkungannya. Masa anak-anak usia sekolah dasar juga merupakan pondasi lanjutan dari masa usia dini dalam menanamkan nilai agamamoral sebagai bekal kehidupan. Halhal apa saja yang menjadi pendukung dari dalam dan luar sehingga anak mencapai nilai agama dan moral sesuai dengan perkembangannya. Pendidikan Moral memerlukan keterlibatan semua aspek kehidupan manusia, sehingga penekanan tidak hanya pada kognitifnya saja. Namun pendidikan moral agama bagi anak usia sekolah dasar harus disesuaikan dengan perkembangan jiwa anak, mengembangkan seluruh aspek kehidupan manusia (Kusrahmadi, 2007). Penyimpangan perilaku anak usia dasar yang saat ini sangat meresahkan dunia pendidikan terjadi karena lemahnya pondasi nilai agama dan moral mereka. Akan tetapi, ketika peneliti observasi keadaan di MI Ma'arif Bego Kecamatan Depok Kabupaten Sleman terlihat pemandangan yang berbeda. Ketika sampai di Madrasah, siswa tengah salat dhuha dan tadarus bersama serta ketika kami melewati beberapa siswa mereka senyum dan menyapa kami walaupun belum kenal. Hal ini menjadi menarik untuk ditelusuri 
IFAT NABILAH,

ISWATUN KHOIRIAH \&

SUYADI

bagaimana keseharian mereka baik di lingkungan sekolah, keluarga dan masyarakat serta bagaimana mereka dapat mencapai tahap perkembangan nilai agama dan moral yang dapat dikatakan mereka telah berhasil mecapainya untuk seusia dasar saat ini.

Berdasarkan penelitian sebelumnya, telah dilakukan penelitian dalam menganalisis perkembangan moral siswa (Farida \& Lestari, 2017; Fitria, 2016; Hasanah, 2018; Safitri \& Aziz, 2019) Namun, belum terdapat penelitian yang menganalisis mengenai perkembangan nilai agama dan moral anak usia dasar. Keterbaruan penelitian ini terletak pada analisis perkembangan nilai agama dan moral anak usia dasar. Sehingga, tujuan penelitian ini adalah untuk menganalisis perkembangan nilai agama dan moral anak usia dasar yang tercapai pada siswa di MI Ma'arif Bego

\section{B. METODE PENELITIAN}

Jenis Penelitian yang digunakan yaitu penelitian kualitatif deskriptif, dimana penelitian ini bertujuan untuk mendeskripsikan dan menganalisis data deskriptif yang dihasilkan yang berupa kata-kata dari orang-orang dan perilaku yang dapat diamati. Data yang diambil berdasarkan studi lapangan yang dilakukan peneliti. Penggunaan studi lapangan ini dikarenakan dengan studi lapangan peneliti dapat mendapatkan informasi dari narasumber terkait perkembangan nilai agama dan moral anak usia dasar yang tercapai.

Dalam pengumpulan data, peneliti menggunakan teknik wawancara yang merupakan cara untuk memperoleh data dari narasumber atau responden yang menjadi objek penelitian. Wawancara juga sebagai teknik untuk mengetahui karakteristik anak, wawancara ini dilakukan dengan obrolan ringan tetapi bermakna untuk menggali informasi. Pada teknik wawancara ini, peneliti melakukan wawancara kepada guru, dan anak didik yang bersangkutan guna mengetahui bagaimana perilaku dan sikap perkembangan nilai agama dan moral yang tercapai pada anak usia sekolah dasar, dari segala kegiatan di sekolah, di rumah dan di lingkungan bermain anak. Peneliti juga melakukan kajian pustaka dari berbagai sumber untuk melengkapi dan mempertajam data-data yang terkait dengan topik yang dibahas.

\section{HASIL PENELITIAN DAN PEMBAHASAN}

1. Karakteristik Anak Usia Dasar

Usia sekolah dasar (7 tahun-12 tahun) merupakan tahapan penting bagi perkembangan seorang peserta didik. Masa sekolah dasar menjadi masa yang cukup panjang dalam pendidikan. Sebagai kelanjutan dari pendidikan sebelumnya (usia dini), pada rentang usia ini juga menjadi fundamental bagi kesuksesan perkembangan pendidikan selanjutnya. Karakteristik umum anak pada dasarnya menggambarkan tentang kondisi siswa seperti usia, kelas, pekerjaan dan gender. Karakteristik siswa merupakan ciri khusus yang dimiliki masing-masing siswa baik sebagai individu atau kelompok sebagai pertimbangan dalam proses pengorganisasian 
IFAT NABILAH,

ISWATUN KHOIRIAH \&

SUYADI

pembelajaran (Winkel, 1996). Masa usia sekolah dasar sering disebut sebagai masa intelektual atau masa keserasian bersekolah. Pada masa keserasian bersekolah ini secara relatif, anak-anak lebih mudah di didik daripada masa sebelum dan sesudahnya (Yusuf, 2016).

2. Perkembangan, Nilai Agama dan Moral

Perkembangan dapat diartikan sebagai proses perubahan yang progresif dan kontinyu (berkesinambungan) dalam diri individu mulai dari lahir hingga mati (the progressive and continous change in the organism from birth to death). Perkembangan dapat diartikan juga sebagai perubahan yang dialami individu atau organisme menuju tingkat kedewasaan atau kematangan (maturattion) yang berlangsung secara sistematis, progesif, dan berkesinambungan baik fisik (jasmaniah) maupun psikis (rohaniah) (Yusuf, 2016).

Agama merupakan tuntutan hidup yang dapat membebaskan manusia dari kekacauan. Di dunia barat agama sering disebut sebagai religion yang berarti melakukan suatu perbuatan dengan penuh penderitaan atau mati-matian. Dalam Islam sendiri, agama berupa wahyu Allah yang diturunkan melalui para Nabi yang berisi perintah dan larangan (Yusuf, 2005). Nilai-nilai atau kaidah yang terkandung dalam agama selaras dengan fitrah manusia sebagai mahluk beragama. Seseorang yang telah berpedoman agama sebagai dasar rujukan perilaku, dan sebagai kompas kehidupan maka ia telah terbebas dari kebodohan dan memperoleh pencerahan hidup.

Istilah moral berasal dari bahasa Latin "mores" yang artinya tata cara dalam kehidupan, adat istiadat, atau kebiasaan. Moral pada dasarnya merupakan rangkaian nilai tentang berbagai macam perilaku yang harus dipatuhi (Asrori, 2012). Sedangkan moralitas merupakan kemauan untuk menerima dan melakukan peraturan, nilai-nilai atau prinsip-prinsip moral. Nilai-nilai moral itu seperti seruan untuk berbuat kebaikan dan larangan untuk berbuat keburukan (Yusuf, 2016). Perkembangan moral ialah kelangsungan mempelajari standar moral serta norma sosial. Situasi yang fungsional lah yang melandasi ekspresi pertimbangan moral (Kurtinez, 1992). Moral agama mempunyai kekuatan yang lebih besar dalam memberikan pengaruh terhadap kehidupan individu. Moral agama harus bersumber dari nash $\mathrm{Al}$ Qur'an yang dijelaskan oleh Hadits Nabi saw dan perkembangan pemikiran ulama yang islami. Moral agama sebagai disiplin ilmu yang berarti ilmu pengetahuan yang mengkaji baik dan buruknya tingkah laku, pola pikir, tutur kata manusia dengan standar Al-Qur'an (Muslih, 1987).

\section{Tahap Perkembangan Agama dan Moral Anak Usia Dasar}

Tahapan perkembangan agama yang terkenal menurut James Fowler adalah theory of faith. Dalam teori ini, Fowler mengusulkan 6 tahap teori perkembangan agama yang dihubungkan dengan teori-teori perkembangan Erikson, Piaget, dan Kohlberg. 
Tabel 1

Tahap Perkembangan Agama menurut James Fowler (Desmita, 2006)

\begin{tabular}{|c|c|c|}
\hline Tahap & Usia & Karakteristik \\
\hline $\begin{array}{l}\text { Tahap } 1 \\
\text { Intuitive-projective faith }\end{array}$ & $\begin{array}{l}\text { Awal masa } \\
\text { anak-anak }\end{array}$ & $\begin{array}{l}\text { - Gambaran intituitif dari kebaikan dan } \\
\text { kejahatan; fantasi dan kenyataan adalah sama }\end{array}$ \\
\hline $\begin{array}{l}\text { Tahap } 2 \\
\text { Mythical-literal faith }\end{array}$ & $\begin{array}{l}\text { Akhir masa } \\
\text { anak-anak }\end{array}$ & $\begin{array}{l}\text { - Pemikiran lebih logis dan konkrit; kisah-kisah } \\
\text { agama diinterpretasikan secara harfiah; tuhan } \\
\text { digambarkan sebagai figur orang tua. }\end{array}$ \\
\hline $\begin{array}{l}\text { Tahap } 3 \\
\text { Synthetic-conventional } \\
\text { faith }\end{array}$ & $\begin{array}{l}\text { Awal masa } \\
\text { remaja }\end{array}$ & $\begin{array}{l}\text { - Pemikiran lebih abstrak; menyesuaikan diri } \\
\text { dengan keyakinan agama orang lain. }\end{array}$ \\
\hline $\begin{array}{l}\text { Tahap } 4 \\
\text { Individuative-reflective } \\
\text { faith }\end{array}$ & $\begin{array}{lr}\text { Akhir masa } \\
\text { remaja dan } \\
\text { awal masa } \\
\text { dewasa }\end{array}$ & $\begin{array}{l}\text { - Untuk pertama kali individu mampu memiliki } \\
\text { tanggungjawab penuh terhadap keyakinan } \\
\text { agama mereka; menjelajahi kedalaman } \\
\text { pengamalan nilai-nilai dan keyakinan agama } \\
\text { seseorang. }\end{array}$ \\
\hline $\begin{array}{l}\text { Tahap } 5 \\
\text { Conjuctive faith }\end{array}$ & $\begin{array}{l}\text { Pertengahan } \\
\text { masa dewasa }\end{array}$ & $\begin{array}{l}\text { - Lebih terbuka terhadap pandangan- } \\
\text { pandangan paradoks dan bertentangan; } \\
\text { berasal dari kesadaran akan batasan dan } \\
\text { pembatasan seseorang }\end{array}$ \\
\hline $\begin{array}{l}\text { Tahap } 6 \\
\text { Universalizing }\end{array}$ & Akhir masa & $\begin{array}{l}\text { - Sistem kepercayaan transdental untuk dewasa } \\
\text { mencapai perasaan ketuhanan; peristiwa- } \\
\text { peristiwa konflik tidak semuanya dipandang } \\
\text { sebagai paradoks. }\end{array}$ \\
\hline
\end{tabular}

Perkembangan beragam pada fase masa anak (usia Sekolah Dasar: 6 tahun - 12 tahun) berdasarkan kesadaran beragama anak menurut Syamsu Yusuf sebagai berikut:

Tabel 2.

Perkembangan dan aktualisasi beragama fase masa anak (Yusuf, 2005).

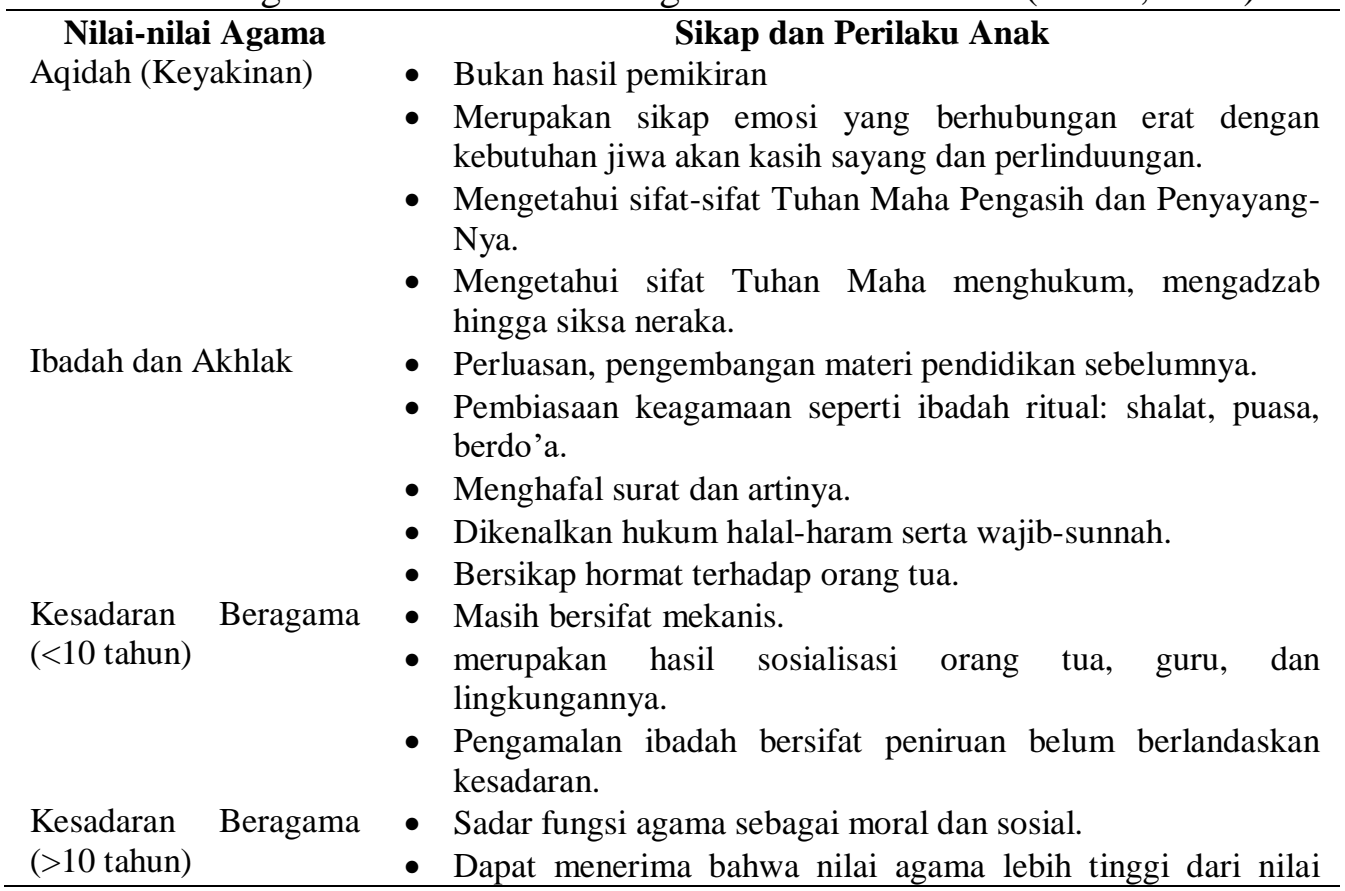


IFAT NABILAH,

ISWATUN KHOIRIAH \&

SUYADI

pribadi/keluarga.

- Sadar dalam melaksanakan kewajiban beribadah.

Tahapan perkembangan moral diklasifikasikan oleh Kohlberg dalam 3 tingkat dan 6 tahap. Kohlberg menjelaskan tahap perkembangan moral terjadi dari aktivitas spontan dari anak-anak yang berkembang melalui interksi sosial, namun interaksi ini mempunyai corak yang khusus dimana faktor pribadi yaitu aktivitas anak ikut berperan.Hal penting lain dari teori perkembangan moral Kohlberg ini adalah orientasinya untuk mengungkapkan moral yang hanya ada dalam pikiran dan yang dibedakan dengan tingkah laku moral dalam arti perbutan yang nyata (Desmita, 2006) dengan semakin tingginya tahap perkembangan moral seseorang akan semakin terlihat moralitas yang lebih tinggi pula.

Tabel 3.

Tingkat dan Tahap Perkembangan Moral Menurut Kohlberg (Kohlberg, 1995)

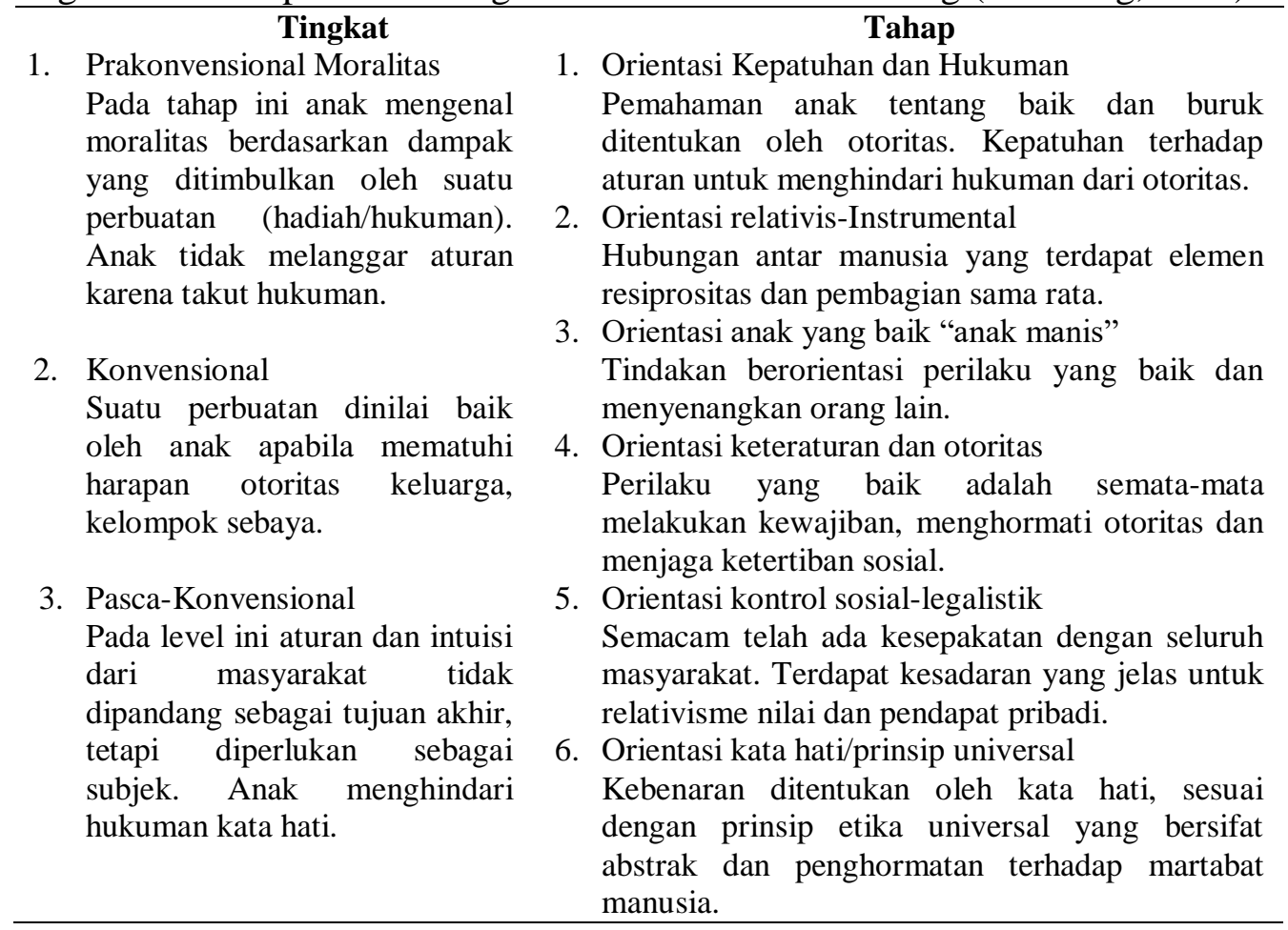

1. Analisis Perkembangan nilai agama dan moral anak yang tercapai di MI Ma'arif Bego, Sleman Yogyakarta

Analisis perkembangan nilai agama dan moral yang tercapai pada subjek ini hanya dilakukan berdasarkan usia subjek kelas atas di Madrasah Ibtidaiyah karena subjek yang diteliti duduk di kelas 6 dan berusia 12 tahun adalah sebagai berikut:

a. Perkembangan agama anak dengan subjek yang duduk di kelas 6 dengan usia 12 tahun

Berdasarkan Tabel 1 di atas dapat ditarik kesimpulan bahwa anak usia akhir masa anak-anak dapat 
IFAT NABILAH,

ISWATUN KHOIRIAH \&

SUYADI

dikategorikan pada pada Tahap 2: Mythical-literal faith. Dimana anak pada usia 12 tahun memiliki karakteristik pemikiran yang lebih logis dan konkrit, menginterpretasikan kisah agama secara harfiah dan menggambarkan figur tuhan sebagai orang tua. Berdasarkan wawancara dengan guru, didapatkan bahwa subjek memang mencapai tahap Mythicalliteral faith. Didukung dengan guru memilih anak tersebut sebagai subjek dengan kategori agama dan moral yang tercapai. Subjek memiliki karakteristik yang sesuai dengan perkembangan agama menurut James Fowler di atas berdasarkan usia subjek.

Dikatakan oleh Elizabeth B. Hurlock dalam bukunya, dengan meningkatnya pemahaman dan keragaman pengalaman, konsep mereka berubah. Contohnya konsep Tuhan sebagai orang tua, akan dipengaruhi pengalaman dengan ayah mereka sendiri dan pengalaman teman mereka. Kemudian dengan bertambahnya usia, kemampuan penalaran mereka meningkat, pengalaman meluas, belajar dari pengalaman, dan fakta-fakta yang sering bertentangan dengan apa yang telah dipelajari. Kemungkinan mereka juga menemukan perbedaan konsep dengan teman-teman yang lain (Hurlock, 1993). Senada dengan deskripsi diatas, berdasarkan hasil wawancaa dengan subjek, bahwa subjek memiliki pemikiran yang logis dan konkrit, hal itu dapat dijelaskan oleh subjek dimana subjek sadar dengan yang dilaksanakan sehari-hari, bagaimana konsep antara teori dengan praktik nyata terkait nilai agama serta pengamalannya dan menjadikan orang tua sebagai teladan bagi subjek. b. Perkembangan kesadaran beragama anak berdasarkan nilai-nilai agama pada subjek

1) Aqidah

Pada nilai-nilai aqidah, sikap dan perilaku subjek telah mencapai indikator yang dipaparkan pada Tabel 2 di atas. Berdasarkan hasil wawancara dengan subjek, subjek telah merasakan adanya kebutuhan dalam berkeyakinan, subjek memahami akan adanya sifat Tuhan yang Maha Pengasih dan Penyayang. Subjek juga memahami jika melanggar aturan Allah akan mendapatkan dosa dan siksa di neraka. Dengan demikian nilai-nilai agama tentang aqidah sudah dicapai oleh subjek. Ketika diminta untuk memberikan contoh subjek menjelaskan saat lupa melaksanakan sholat atau terlambat subjek merasa bersalah.

\section{2) Ibadah dan Akhlak}

Pada nilai-nilai ibadah dan akhlak, sikap dan perilaku subjek telah mencapainya meskipun belum sepenuhnya. Berdasarkan hasil wawancara dengan subjek, subjek telah menguasai dan mengembangkan materi dari pendidikan sebelumnya. Dalam pembiasaan beribadah ritual, kewajiban seperti sholat, puasa dan berdo'a telah dilaksanakan dengan tertib, ditambah pembiasaan dari kebijakan sekolah untuk melaksanakan sholat dhuha setiap pagi di sekolah. Hafalan surat beserta artinya juga menjadi suatu aspek yang telah dicapai subjek berdasarkan kegiatan disekolah. Subjek juga telah mengenal hukum halah-haram serta wajib-sunnah. Terkait sikap hormat terhadap orang 
IFAT NABILAH,

ISWATUN KHOIRIAH \&

SUYADI

tua, subjek menjelaskan jika ia patuh pada orang tua, menyadari akan tanggungjawabnya sebagai anak, menghormati orang tua namun dalam berbahasa kepada orang tua belum menggunakan bahasa jawa yang halus karena lebih sering menggunakan bahasa Indonesia.

\section{3) Kesadaran Beragama}

Pada nilai kesadaran beragama kita mengacu pada usia diatas 10 tahun, dimana subjek berusia 12 tahun. Berdasarkan hasil wawancara, subjek telah mencapai nilai kesadaran dalam beragama sebagai nilai dalam moral dan sosialnya. Subjek juga menerima bahwa agama adalah kepercayaan masyarakat, seperti halnya pelaksanaan ibadah sholat berjamaah, sholat hari raya dan ibadah sosial menjadi hal yang menarik, namun ketika dirumah praktik sholat berjamaah belum maksimal dilaksanakan. Subjek juga menyadari bahwa melaksanakan kewajiban adalah suatu ibadah meskipun terkaang masih diingatkan dalam pelaksanaannya.

\section{c. Perkembangan moral anak berdasarkan teori perkembangan moral Kohlberg}

Anak usia kelas atas Sekolah Dasar (subjek kelas 6 usia 12 tahun) dapat dikategorikan dalam tingkat konvensional pada tahap 3 dan 4 . Kohlberg meyakini bahwa tingkatan dan tahapan ini terjadi secara berurutn sesuai dengan usia. Sebelum usia 9 tahun, anak menggunakan tingkat 1 , dan ketika akhir masa anak-anak menuju awal remaja, kebanyakan mereka telah mencapai tingkat 2 yaitu konvensional (Amrah, 2013).

Fase konvensional ini dibagi menjadi 2 tahap, yakni tahap ketiga: orientasi anak yang baik terkait hubungan dengan orang lain dimana anak menyadari perilaku yang bermoral akan berdampak kepada orang lain dan harus menyenangkan orang lain. Subjek menjelaskan bahwa dalam berhubungan dengan orang lain perlu memperhatikan kepercayaan, kepedulian, saling berbagi dan tidak memilih teman bergaul. Berbagai hal tersebut sudah sesuai dengan teori yang ditetapkan oleh Kohlberg. Pada tahap keempat: dalam bersikap dan berperilaku, ada aturan atau standar tertentu yang telah ditetapkan masyarakat maupun pemerintah. Dalam hal ini subjek telah mencapainya dengan mematuhi peraturan yang ada dalam masyarakat seperti rutin mendatangi TPA di lingkungan rumah serta aturan-aturan lainnya.

Subjek dapat menyebutkan beberapa peraturan kelas yang tidak boleh dilanggar, antara lain: dilarang tidur di kelas selama jam pelajaran berlangsung, tidak boleh membuat gaduh di kelas, dilarang menyontek hasil pekerjaan teman sekelas (tugas individu), tidak mengerjakan pekerjaan rumah, tidak melaksanakan piket kelas yang telah terjadwal, bercengkerama dengan teman sebangku ketika guru menjelaskan.

Subjek pernah melanggarnya, yakni bercengkerama dengan teman sebangku ketika guru sedang menerangkan. Tapi itu dulu ketika kelas 3, seiring bertambahnya umur, kedewasaan berpikir dan moral peserta didik, maka hal tersebut tidak pernah terulangi lagi, termasuk pelanggaran lainnya, sampai 
IFAT NABILAH,

ISWATUN KHOIRIAH \&

SUYADI

sekarangkelas 6. Ada dampak positif walau kecil ketika anak tersebut melakukan pelanggaran kemudian dihukum dengan menulis latin "saya tidak akan mengulangi lagi" pada selembar kertas penuh. Ada efek jera karena harus menulis latin berulangkali serta malu karena teman sekelasnya tahu baahwa Alifia dihukum guru karena bercengkerama ketika guru sedang menerangkan.

2. Analisis faktor perkembangan tercapainyanilai agama dan moral anak di MI Ma'arif Bego, Sleman Yogyakarta

Berdasarkan hasil analisis perkembangan nilai agama-moral anak di atas, secara garis besar dapat ditarik kesimpulan adanya beberapa faktor yang mempengaruhi tercapainya perkembangan nilai agama-moral pada anak usia sekolah dasar. Adapun faktor tercapainya nilai agama-moral anak pada subjek dapat digambarkan sebagai berikut:

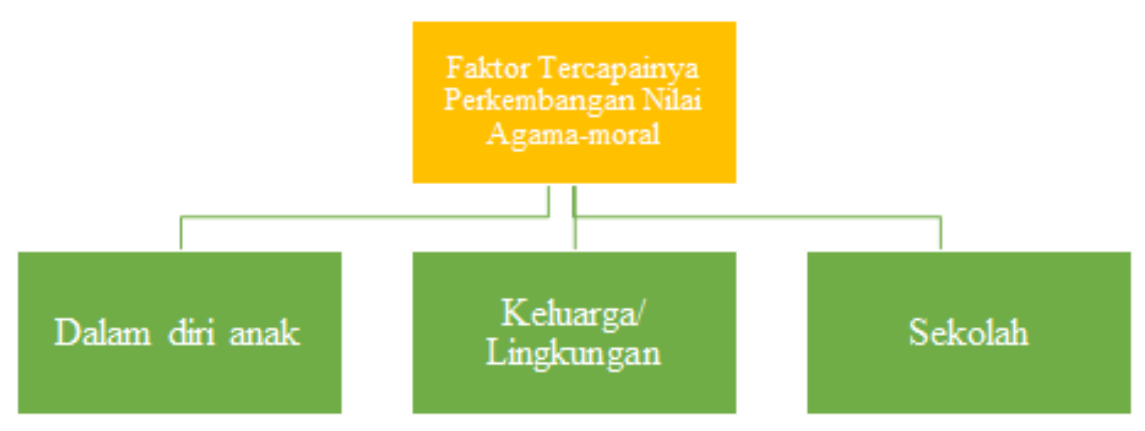

Gambar 1. Faktor Tercapainya Perkembangan Nilai Agama-Moral subjek

Gambar 1 menunjukkan bahwa fator pendukung tercapainya nilai agamamoral anak pada subjek ada 3 faktor yakni dalam diri anak, keluarga/lingkungan, dan sekolah. Deskripsi dari ketiga faktor tersebut adalah sebagai berikut:

\section{a. Internal/dari dalam diri anak}

Dikemukakan oleh Yusuf (2012), faktor genetik/hereditas merupakan faktor internal yangberpengaruh terhadap pertumbuhan dan perkembangan individu. Hereditas sendiri dapat diartikan sebagai totalitas karakteristik individu yang diwariskan orang tua. Sejalan dengan itu, faktor genetik dapat diartikan sebagai segala poteensi (baik fisik maupun psikis) yang dimiliki individu sejak masa prakelahiransebagai pewarisan dari pihak orang tua melalui gen-gen. Dari definisi tersebut, yang perlu digaris bawahi adalah faktor ini bersifat potensial, pewarisan/bawaan dan alamiah (nature) (Latifa, 2017).

\section{b. Keluarga/lingkungan}

Konsep ajaran Islam menegaskan bahwa pada hakikakatnya jin dan manusia adalah untuk menjadi pengabdi yang setia kepada Penciptanya (Q.S. Adz-Dzariyat: 56). Agar tugas dan tanggungjawab tersebut dapat diwujudkan secara benar, Tuhan mengutus Rasul-Nya sebagai pemberi pengajaran, contoh, 
IFAT NABILAH,

ISWATUN KHOIRIAH \&

SUYADI

dan teladan. Dalam estafet

kulikulernya yang mendukung berikutnya, risalah kerasulan itu diwariskan kepada para ulama. Akan tetapi tanggung jawab utamanya dititikberatkan pada orangtua (Arifin, 2008).

Dalam hal ini, orang tua Alifia dari kecil hingga sekarang selalu mengajarkan hal-hal yang berkaitan dengan agama, baik itu hal-hal yang diwajibkan maupun yang dilarang oleh agama. Peran orang tua dalam membimbing agama anaknya adalah agar anaknya berada di "jalan yang benar". Pembimbingan tersebut merupakan bukti bahwa keluarga merupakan pendidik dasar yang pertama bagi anak-anaknya. Pendidikan keluaga juga merupakan pendidik dasar bagi pembemtukan jiwa keagamaan pada anak, dalam hal ini orang tua maupun keluarga inti.

Dorongan keberagamaan merupakan faktor bawaan manusia. Apakah setelah dewasa seseorang kelak akan menjadi sosok penganut agama yang taat atau tidak, hal itu sepenuhnya bergantung pada pembinaan nilainilai agama oleh kedua orangtua. Karena keluarga merupakan pendidikan dasar yang pertama bagi anak-anak, lembaga pendidikan merupakan penerus dan penguat dari pondasi.

\section{c. Sekolah}

Lembaga pendidikan merupakan pelanjut dari pendidikan rumah tangga. Madrasah Ibtidaiyah Ma'arif Bego pun di sini punya peran yang cukup penting juga karena mengajarkan agama secara lebih luas melalui mata pelajaran agamanya seperti tarikh, bahasa arab, aqidah akhlak, Al-Qur'an Hadits, serta Fiqih. Selain itu, kegiatan ektra seperti BTQH, Qiro'ati dan sebagainya. Selain itu, guru-gurunya selain mengajarkan juga mencontohkan serta lingkungan sekolah yang mendukung untuk perkembangan agama Alifia dan teman-temannya.

Perkembangan agama yang dapat tercapai dengan baik pada anak-anak usia sekolah dasar dapat menghindarkan diri dari perilakuperilaku penyimpangan agama seperti kenakalan remaja, penggunaan narkotika, zat adiktif, dan minuman keras, perilaku free seks, pelacuran, sodomi, homo seks serta lesbian (Khairunnas, 2012).

Gejala yang tampak pada perkembangan nilai, moral dan sikap antara lain dalah:

a. Terbentuknya pandangan hidup yang semakin jelas dan tegas.

b. Berkembangnya pemahaman tentang apa yang baik dan seharusnya dilakukan serta apa yang dianggap tidak baik dan tidak boleh dilakukan.

c. Berkembangnya sikap untuk menghargai nilai-nilai dan norma-norma yang berlaku seta mewujudkannya ke dalam kehidupan sehari-hari.

d. Berkembangnya sikap menentang terhadap kebiasaan-kebiasaan yang dianggap tidak sesuai dengan norma yang

\section{SIMPULAN DAN SARAN}

Berdasarkan hasil dan pembahasan dapat disimpulkan bahwa faktor pendukung tercapainya nilai agamamoral anak pada subjek ada 3 faktor yakni, internal/dari dalam diri anak, keluarga, sekolah dan lingkungan. 
IFAT NABILAH,

ISWATUN KHOIRIAH \&

SUYADI

Ketiga faktor tersebut harus saling mendukung, mengawasi, mengingatkan, membimbing, memberi contoh serta menjaga satu sama lain agar tercipta generasi penerus bangsa yang taat beragama dan bermoral tinggi. Dengan tercapainya nilai agama dan moral pada siswa usia dasar, maka akan menjauhkan siswa usia dasar dari perilaku maupun hal-hal yang menyimpang seperti bullying, mencuri,merokok, berani melawanorangtua, tidak menghormati guru serta yang memprihatinkan saat ini adalah perilaku seks bebas dan narkoba.

Adapun saran untuk peneliti selanjutnya agar dapat menganalisis aspek lain yang ada pada diri siswa, serta peneliti menyarankan pihak kepada pihak keluarga, sekolah dan lingkungan hendaknya saling mendukung, mengawasi, mengingatkan, mendampingi serta membimbing remaja (anak usia dasar) agar tidak terpengaruh oleh budaya-budaya negatif yang membuat mereka terjebak kedalam pergaulan bebas dengan moral yang memprihatinkan.

\section{E. DAFTAR PUSTAKA}

Amrah. (2013). Perkembangan Moral Anak Usia Sekolah Dasar. Publikasi Pendidikan.

Arifin, B. S. (2008). Psikologi Agama. Bandung: Pustaka Setia.

Asrori, M. (2012). Psikologi Pembelajaran. Bandung: CV Wacana Prima.

Damanik, C. (2018). Gara-gara cetak gol bunuh diri siswa SD dianiaya teman teman hingga masuk.
Desmita. (2006). Psikologi Perkembangan. Bandung: PT Remaja Rosda Karya.

Farida, N., \& Lestari, M. (2017). Analisis Perkembangan Moral Anak Usia Dini Yang Memiliki Ibu Tenaga Kerja Wanita (TKW) di TK Aisyiyah Bajang Mlarak Ponogoro. SOSIAL: Jurnal Penelitian Ilmu Ilmu Sosial, 18(2), 140-144.

Fitria, R. (2016). Perkembangan Moral Siswa SMP Terhadap Permasalahan Lingkungan Pendulangan Intan Melalui Penyelesaian Masalah. In Proceeding Biology Education Conference (pp. 145-150).

Hasanah, U. (2018). Metode Pengembangan Moral Dan Disiplin Bagi Anak Usia Dini. Martabat: Jurnal Perempuan Dan Anak, 2(1), 92-116.

Hurlock, E. B. (1993). Perkembangan Anak (Jilid II). Erlangga: Erlangga.

Khairunnas. (2012). Psikologi Agama. Yogyakarta: Aswaja Presindo.

Kohlberg, L. (1995). Tahap-tahap Perkembangan Moral. Yogyakarta: Kanisius.

Kurtinez, W. (1992). Moralitas, Perilaku Moral dan Perkembangan Moral. Jakarta: UI Press.

Kusrahmadi, S. D. (2007). Pentingnya Pendidikan Moral Bagi Anak Sekolah Dasar. Dinamika Pendidikan.

Latifa, U. (2017). Aspek Perkembangan pada Anak Sekolah Dasar: Masalah dan Perkembangannya. Academia, Vol 1 No.2.

Muslih. (1987). Moral Agama, Suluh Kepribadian Pemuda Menghadapi Arus Budaya 
IFAT NABILAH,

ISWATUN KHOIRIAH \&

SUYADI

Massa. Dirjen Bimbaga Islam.

Safitri, L. N., \& Aziz, H. (2019). Pengembangan Nilai Agama dan Moral Melalui Metode Bercerita Pada Anak. Jurnal Ilmiah Tumbuh Kembang Anak Usia Dini, 4(1), 85-96.

Winkel, W. (1996). Psikologi Pengajaran. Jakarta: Grasindo.

Yusuf, S. (2005). Psikologi Belajar Agama: Prespektif Pendidikan Agama Islam. Bandung: Pustaka Bani Quraisy.

Yusuf, S. (2016). Psikologi Perkembangan Anak dan Remaja. Bandung: PT Remaja Rosda Karya. 